\title{
Burnout syndrome and abdominal adiposity among Primary Health Care nursing professionals
}

\author{
Magno Conceição das Merces ${ }^{1,2^{*}}$, Douglas de Souza e Silva ${ }^{4}$, Iracema Lua ${ }^{3}$, Daniela Sousa Oliveira ${ }^{4}$, \\ Marcio Costa de Souza ${ }^{1}$ and Argemiro D'Oliveira Júnior ${ }^{2}$
}

\begin{abstract}
Background: Accumulation of abdominal adiposity (AA) constitutes a risk factor for heart and coronary diseases and for metabolic complications. Research suggests that stress is related to adipogenesis. The burnout syndrome (BS) is linked to stress due to the chronicity of work stress. The objective of this study is to estimate the association between BS and AA in Primary Health Care (PHC) nursing practitioners.

Methods: This is confirmatory cross-sectional study with 189 workers from nine municipalities in Bahia, Brazil. The dependent variable was AA, measured by waist circumference. The independent variable was the BS, diagnosed by the Maslach Burnout Inventory (MBI). Sociodemographic and job characteristics, lifestyle, and human biology were taken as covariates and were evaluated as modifiers or confounders by the homogeneity tests and by comparison with the adjusted Mantel-Haenszel test, respectively. Logistic regression was employed to evaluate the association between BS and AA, adjusted for covariates. The adequacy of the final regression model was evaluated by the model's goodness of fit test and the area under the ROC curve.
\end{abstract}

Results: BS prevalence was $10.6 \%$ and AA 54\%. The variables age, education, hypertension, diabetes, working time, and high emotional exhaustion were associated with AA. An association was found between BS and AA (1.63 adjusted prevalence ratios; $95 \% \mathrm{Cl}, 1.29$ to 2.06) even after age and working time adjustment.

Conclusion: The results suggest an association between BS and AA in the analyzed professionals. A significant prevalence of burnout and AA is highlighted.

Keywords: Occupational stress, Burnout, Abdominal adiposity, Nursing team, Primary Health Care

\section{Background}

Stress has as initial function adjusting homeostasis and improving the individual's ability in order to ensure their survival. The stimulus or stress agent is an element that affects the homeostatic balance of the body, and stress is the response to this stimulus. The way we deal with stress can make the difference between health and illness (Benevides-Pereira 2010). The body sets off a series of neurological and hormonal processes aiming to face the stress stimulus. In their genesis, systemic responses to

\footnotetext{
* Correspondence: mmerces@uneb.br; magnomerces@hotmail.com 'Universidade do Estado da Bahia, Departamento de Ciências da Vida. Rua Silveira Martins, 2555, Cabula, Salvador, Bahia CEP 41150000, Brazil ${ }^{2}$ Programa de Pós Graduação em Ciências da Saúde, Universidade Federal da Bahia, Salvador, Bahia, Brazil

Full list of author information is available at the end of the article
}

stress are considered beneficial; however, chronic stress can cause systemic problems. The duration and intensity of stress can cause short- or long-term effects, disrupting homeostasis, even resulting in a pathological process (Smeltzer et al. 2009).

Thus, the stress response is related to the hypothalamicpituitary-adrenal (HPA) axis. An increase in the routine stress can result in physiological and neuroendocrine changes, which stimulate the ingestion of calorie foods and, consequently, the increase of adipogenesis (Miller et al. 2007; Oliveira et al. 2013).

Stress related to work, known as occupational stress, whose stressors are linked to the work environment, is constituted by the association of various symptoms presented by the body and can trigger physical and mental diseases (Ribeiro et al. 2015 p. 436). 
Linked to occupational stress is the burnout syndrome (BS). Characterized by emotional exhaustion (EE), depersonalization (DP), and low professional accomplishment (LPA), it can affect those professionals whose work requires direct contact with the public (Tironi et al. 2009; Sousa and Medonça 2009). Burnout involves negative attitudes and behaviors with regard to labor activities, resulting in emotional and labor practice problems (Murofuse et al. 2005).

Some authors emphasize that this syndrome is inherent to the working environment, being triggered by failures to cope with chronic work stress making the professional less sensitive to environmental and labor issues (Benevides-Pereira 2003; Gil-Monte 2003; Limongi-França and Rodrigues 2005). Thus, chronic workplace stress provides its emergence (Björntorp 2001).

Stressful work situations stimulate the response of the HPA axis leading to insulin resistance as a result of an excessive cortisol production (Costa et al. 2011). Increased cortisol levels released by the adrenal medulla, associated in turn by stimulation of the adrenocorticotropic hormone (ACTH) released by the pituitary, would be related to abdominal adiposity, as there is mobilization of lipids from the adipose tissue, and of glucose from liver glycogen, to increase the amount of available energy for stressful situations (Rosmond and Bjorntorp 2000).

A study shows that too much occupational stress can lead the professional to develop BS and, consequently, metabolic diseases (Merces et al. 2015). Some other studies have shown a positive association between abdominal adiposity (AA) and cardiovascular responses to mental stress (Goldbacher et al. 2005; Steptoe and Wardle 2005; Davis et al. 1999; Waldstein et al. 1999). Among the risk factors for the development of AA and its metabolic and cardiovascular consequences, situations of occupational stress are found (Chandola et al. 2006; Tsigos and Chrousos 2006).

AA accumulation constitutes a risk factor for heart and coronary diseases and for metabolic complications. It is not just an aesthetic issue but an important indicator for the workers' health (Martins and Marinho 2003; Ammar et al. 2008). Excess of AA can increase up to ten times the risk for developing type 2 diabetes and is a major risk factor for hypertension in adults (Francischi et al. 2000). Noteworthy is the higher health risk when compared to other forms of body fat distribution (Oliveira et al. 2015).

In the interim, the impact of work on health is nowadays being studied and discussed. The health conditions of health workers have emerged as a commonly discussed problem, taking into account the complexity of the demands of the health sector. In this scenario, the nursing professionals who make up a large contingent of this labor force are often overwhelmed by the accumulation of work and professionally undervalued. In the context of Primary Health Care (PHC), little is known about the health conditions of the professionals inserted in this level of caretaking (Davis et al. 1999).

Among the factors that contribute to the emergence of stress and hence to the BS in PHC nursing professionals, we find the complexity of interpersonal relationships, a work environment typically inserted into a community, the relationship with users, and an inadequate human and material resources planning (Merces et al. 2016; Ribeiro et al. 2015).

Given the above information, this study aimed to estimate the association between burnout syndrome and abdominal adiposity in $\mathrm{PHC}$ nursing practitioners.

\section{Methods}

We conducted a confirmatory, cross-sectional, epidemiological study with Primary Health Care nursing practitioners of nine municipalities in Bahia, Brazil, namely, Anguera, Catu, Guanambi, Ibirapitanga, Igaporã, Inhambupe, Macaúbas, Pojuca, and Santa Barbara, linked to the multicenter project entitled "Síndrome de Burnout e Síndrome Metabólica em Profissionais de Enfermagem da Atenção Básica à Saúde do Estado da Bahia" (Burnout Syndrome and Metabolic Syndrome in Primary Health Care Nursing Professionals of the State of Bahia). The total amount of family health units (FHU), the study's locus, corresponded to 73, and among the 211 nursing professionals, who have developed their working practices regularly, 195 met the inclusion criteria.

It is noteworthy that 16 professionals were excluded because of the following: being on medical leave, develop purely administrative activities, pregnant women, and professionals who reported a diagnosis of depression before entering the position assumed.

From the professionals included in the study, 189 (96.9\%) participated and answered all the questions of the questionnaire, specifically designed for this study, containing information on sociodemographic and job conditions, lifestyle, and human biology as well as a tool to assess the presence of BS, called the Maslach Burnout Inventory (MBI) (Maslach et al 1996). We evaluated the internal reliability of the MBI instrument categories using the Cronbach's alpha coefficient. Alpha values above 0.70 indicate acceptable internal consistency, maintaining the reliability of the instrument, with 0.82 for EE, 0.79 for DP, and 0.81 for LPA.

Data collection was conducted through interviews from January 2015 to March 2016, and all the PHC nursing professionals were invited to participate in the survey by telephone, on which occasion the scope and objectives of the survey were explained to them, emphasizing the nature of voluntary participation. Only six participants refused to participate in the study. We 
performed a pilot study to make the necessary adjustments in the questionnaire. Moreover, viewing to ensure a uniform application of the questionnaires, we opted for a calibration of the research's assistants by means of the application of questionnaires in ten professionals of the hospitals' field. This procedure was eligible to calculate the rate of agreement between them, using the Kappa index, finding a 0.87 value which is considered acceptable with an optimal classification (Seigel et al. 1992).

The main independent variable of this study was the $\mathrm{BS}$; for the definition of the individual with BS, we remark that the MBI is a validated instrument which was translated into Portuguese in Brazil by Benevides-Pereira (2009). It is composed of 22 questions that explore the three dimensions: $\operatorname{EE}(1,2,3,6,8,13,14,16$, and 20), DP $(5,10,11,15$, and 22), and LPA $(4,7,9,12,17,18$, 19 and 21), scored by a Likert scale of five points which is as follows: "1" never, "2" rarely, "3" sometimes, "4" frequently, and " 5 " always.

From the sum of questions for each dimension, the score was obtained with the following cutoff points: EE, high ( $\geq 27$ points), medium (19-26 points), and low ( $<19$ points); DP, high ( $\geq 10$ points), medium (6-9 points), and low ( $<6$ points); and LPA, high ( $\leq 33$ points), medium (34-39 points), and low ( $\geq 40$ points) (Moreira et al. 2009). The BS was dichotomized according to the criteria by Ramirez et al. (1996), as present (yes) or absent (no), by considering the existence of high scores in the dimensions of EE and DP and low scores on the LPA.

The dependent variable was represented by abdominal adiposity, measured by the individual's waist circumference. The most representative anthropometric verification of intra-abdominal fat, considered simpler measurement, is the measurement of abdominal circumference (AC) or waist circumference (WC) due to its high relation to the amount of visceral adipose tissue (Sociedade Brasileira de Endocrinologia e Metabologia 2005; Scarcela and Despres 2003). It is the best indicator of visceral fat mass being strongly related to cardiovascular complications (Martins and Marinho 2003).

The WC standardization and measurement followed the standards recommended by the Universidade de São Paulo, Laboratório de Avaliação Nutricional de Populações (2010) and the nutrition department. Thus, the WC measurement was obtained using an ISP $^{\bullet}$ inelastic tape made of fiberglass material with a capacity of $150 \mathrm{~cm}$ and $1-\mathrm{cm}$ accuracy. The measure was taken at the midpoint of the distance between the lower edge of the rib cage and the iliac, at horizontal plane. The surveyed professionals were measured in standing position, arms at their sides, feet together, weight divided between the legs, and eyes on the horizon. We requested the professionals to elevate their shirts to measure accurately (Habicht and Butz 1979).
The following cutoffs were used: normal WC $(<88 \mathrm{~cm}$ for women and $<102 \mathrm{~cm}$ for men) and high-risk WC ( $\geq 88 \mathrm{~cm}$ for women and $\geq 102$ for men) (World Health Organization 2005).

After data collection, the questionnaires were examined, numbered to facilitate registering, entered, and processed, using the Statistic Package for Social Sciences (SPSS). We checked for errors and inconsistencies and validated the data presenting the percentage values, the means, and the standard deviations of the variables.

Subsequently, the statistical analysis of the data was carried out using SPSS 22.0 software for Windows and STATA for Windows, in order to assess the predictive conceptual model having AA as dependent variable and $\mathrm{BS}$ as an independent main variable. The independent variables (covariates) considered as potential effect modifiers were as follows: hypertension, diabetes mellitus, and alcohol consumption; the confounding variables were as follows: gender, education, working time at the Health Unit, physical activity, and anxiety.

Initially, we carried out a descriptive analysis by means of absolute and relative frequencies of all the variables of interest, enabling to estimate prevalence from the main independent variable (BS) and the dependent variable (AA). The bivariate analysis was performed to verify the associations of the independent variables with the dependent variable. Therefore, we calculated their prevalence ratios (PR), their respective confidence intervals (CI) of 95\%, and $p$ value through Pearson's chi-square test or Fisher's exact test to assess the statistical significance of the associations.

To confirm the modification of the effect, we calculated the PRs of the main association per stratum of each preselected covariate and their respective 95\% CI. Verification of effect modification was done through the intuitive method (PR of a stratum should not be contained in the confidence interval of another stratum and vice versa) and the Breslow-Day homogeneity test with a $p$ value $\leq 0.05$. As for the confirmation of the confounding variables, we used the variation between crude PR and Mantel-Haenszel's adjusted PR, taking as a selection criterion variation $\geq 20 \%$. In processing the analyses, we found no effect modifying or confounding variables.

To assess the association between BS and AA, controlled by the covariates of interest in the predictive conceptual model, we used conditional logistic regression with the retrograde selection process ("Back Ward"), with analysis criterion value $p \leq 0.05$. To obtain the final logistic regression model, we followed the procedures described by Hosmer and Lemeshow (2000).

It is noteworthy that the logistic regression model produced odds ratio measures (OR) which is not a suitable association measure for cross-sectional studies, and this measure overestimates associations in studies with high- 
prevalence outcomes (over 10\%); therefore, the prevalence ratios (PR) and 95\% confidence intervals were estimated using Poisson's regression with robust variance (Coutinho et al. 2008; Francisco et al. 2008).

The adequacy of the final regression model was evaluated by the model's goodness of fit test (Hosmer and Lemeshow) and the area under the receiver operating characteristic (ROC) curve.

The study was approved by the Ethics in Research Committee involving human beings of the State University of Bahia, in decree no. 872.365/2014. We highlight that all participants signed the consent form.

\section{Results}

Of the 189 study participants, 183 (96.8\%) were female and 106 (56.1\%) were aged up to 35 years. 50.3\% had a high school degree; $64.9 \%$ reported the practice of physical activity; $52.9 \%$ consumed alcohol; $91.5 \%$ reported not being hypertensive; $97.9 \%$ were not diabetic; $64.7 \%$ considered themselves anxious; and $55.6 \%$ had up to 4 years of work in PHC (Table 1)

BS prevalence was $10.6 \%$. Regarding the dimensions of BS, 77 (40.7\%) had average EE and 39 (20.6\%) high exhaustion; 74 (39.2\%) scored average DP and 60 (31.7\%) high DP; 93 (49.2\%) had mean LPA and 91 (48.1\%) high LPA (Table 1).

AA prevalence was $54 \%$. Table 2 shows the bivariate analyses of the sociodemographic and occupational characteristics, lifestyle, and morbidity associated with AA. There were statistically significant associations in the variables age (crude PR $=1.61 ; 95 \% \mathrm{CI}, 1.24$ to 2.10 ); education (crude $\mathrm{PR}=1.6$; $95 \% \mathrm{CI}, 1.20$ to 2.11 ); hypertension (crude $\mathrm{PR}=$ 2.02; $95 \% \mathrm{CI}, 1.74$ to 2.35 ); diabetes (crude $\mathrm{PR}=1.80$; $95 \%$ $\mathrm{CI}, 1.64$ to 2.16 ); working time in a $\mathrm{PHC}$ unit $\geq 5$ years (crude PR =1.7; 95\% CI, 1.31 to 2.24); and high EE (crude $\mathrm{PR}=1.39$; 95\% CI, 1.05 to 1.84 ).

According to the pre-established methodological criteria, modifying or confounding variables were not identified (Table 3).

Although we did not identify an effect modifying and confounding variables in the stratified analysis, in front of the relevance of the variables of gender, age, education, physical activity practice, alcohol consumption, hypertension, diabetes, anxiety, and working time in a PHC unit, we maintained them in the multivariate model to adjust according to the knowledge of their influence both on the exposure factor and on the outcome.

After analyzing the model, we identified that the variables age and working time remained associated with the outcome (adjusted PR 1.63; 95\% CI, 1.29 to 2.06). The hypothesis that the model was well adapted to the data was accepted, and the Hosmer and Lemeshow goodness of fit test showed $p<0.05$, while the ROC curve showed an area of 0.71 , showing
Table 1 Sociodemographic and occupational characteristics, lifestyle, morbidity of the population as important variables for the predictive model $(N=189)$, Bahia, Brazil

\begin{tabular}{|c|c|c|}
\hline Variables & Number & Percent \\
\hline \multicolumn{3}{|l|}{ Sex } \\
\hline Male & 6 & 3.2 \\
\hline Female & 183 & 96.8 \\
\hline \multicolumn{3}{|l|}{ Age } \\
\hline Till 35 years old & 106 & 56.1 \\
\hline 36 or more & 83 & 43.9 \\
\hline \multicolumn{3}{|l|}{ Education } \\
\hline High school & 95 & 50.3 \\
\hline University & 94 & 49.7 \\
\hline \multicolumn{3}{|c|}{ Physical activity practice ${ }^{a}$} \\
\hline Yes & 66 & 35.1 \\
\hline No & 122 & 64.9 \\
\hline \multicolumn{3}{|c|}{ Alcoholic beverage consumption $^{a}$} \\
\hline No & 88 & 47.1 \\
\hline Yes & 99 & 52.9 \\
\hline \multicolumn{3}{|l|}{ Hypertensive $^{a}$} \\
\hline No & 172 & 91.5 \\
\hline Yes & 16 & 8.5 \\
\hline \multicolumn{3}{|l|}{ Diabetic } \\
\hline No & 185 & 97.9 \\
\hline Yes & 4 & 2.1 \\
\hline \multicolumn{3}{|l|}{ Anxious $^{a}$} \\
\hline No & 66 & 35.3 \\
\hline Yes & 121 & 64.7 \\
\hline \multicolumn{3}{|c|}{ Working time at a PHC unit } \\
\hline Up to 4 years & 105 & 55.6 \\
\hline 5 or more years & 84 & 44.4 \\
\hline \multicolumn{3}{|c|}{ Emotional exhaustion } \\
\hline Low & 73 & 38.6 \\
\hline Average & 77 & 40.7 \\
\hline High & 39 & 20.6 \\
\hline \multicolumn{3}{|l|}{ Depersonalization } \\
\hline Low & 55 & 29.1 \\
\hline Average & 74 & 39.2 \\
\hline High & 60 & 31.7 \\
\hline \multicolumn{3}{|c|}{ Reduced professional fulfillment } \\
\hline Low & 5 & 2.6 \\
\hline Average & 93 & 49.2 \\
\hline High & 91 & 48.1 \\
\hline
\end{tabular}

${ }^{a}$ Variables with lost data 
Table 2 Sociodemographic and occupational characteristics, lifestyle, and morbidity related to abdominal adiposity $(N=189)$, Bahia, Brazil, 2016

\begin{tabular}{|c|c|c|c|}
\hline \multirow[b]{3}{*}{ Variables } & \multirow{3}{*}{$\begin{array}{l}\text { High abdominal adiposity risk } \\
\text { Prevalence (54\%) } \\
p(\%)\end{array}$} & \multirow[b]{3}{*}{ PR } & \multirow[b]{3}{*}{$\mathrm{Cl}(95 \%)$} \\
\hline & & & \\
\hline & & & \\
\hline \multicolumn{4}{|l|}{$\operatorname{Sex}^{a}$} \\
\hline Male & $1(16.6)$ & 1.00 & \\
\hline Female & $101(55.1)$ & 3.31 & $0.55-19.91$ \\
\hline \multicolumn{4}{|l|}{ Age } \\
\hline Till 35 years old & $45(42.4)$ & 1.00 & \\
\hline 36 or more & $57(68.6)$ & 1.61 & $1.24-2.10$ \\
\hline \multicolumn{4}{|l|}{ Education } \\
\hline High School & $63(66.3)$ & 1.6 & $1.20-2.11$ \\
\hline University & $39(41.4)$ & 1.00 & \\
\hline \multicolumn{4}{|c|}{ Physical activity practice } \\
\hline Yes & $29(43.9)$ & 1.00 & \\
\hline No & $72(59)$ & 1.3 & $0.99-1.83$ \\
\hline \multicolumn{4}{|c|}{ Alcoholic beverage consumption } \\
\hline No & $50(56.8)$ & 1.00 & \\
\hline Yes & $51(51.5)$ & 0.90 & $0.69-1.18$ \\
\hline \multicolumn{4}{|l|}{ Hypertensive } \\
\hline No & $85(49.4)$ & 1.00 & \\
\hline Yes & $16(100)$ & 2.02 & $1.74-2.35$ \\
\hline \multicolumn{4}{|l|}{ Diabetic $^{a}$} \\
\hline No & $98(52.9)$ & 1.00 & \\
\hline Yes & $4(100)$ & 1.80 & $1.64-2.16$ \\
\hline \multicolumn{4}{|l|}{ Anxious } \\
\hline No & $37(56.0)$ & 1.00 & \\
\hline Yes & $64(52.9)$ & 0.94 & $0.71-1.23$ \\
\hline \multicolumn{4}{|c|}{ Working time at a PHC unit } \\
\hline Up to 4 years & $43(40.9)$ & 1.00 & \\
\hline 5 or more years & $59(70.2)$ & 1.7 & $1.31-2.24$ \\
\hline \multicolumn{4}{|c|}{ Emotional exhaustion } \\
\hline Low & 39 (53.4) & 1.00 & \\
\hline Average & $34(44.1)$ & 0.82 & $0.59-1.15$ \\
\hline High & $29(74.3)$ & 1.39 & $1.05-1.84$ \\
\hline \multicolumn{4}{|l|}{ Depersonalization } \\
\hline Low & $31(56.3)$ & 1.00 & \\
\hline Average & $31(41.9)$ & 0.74 & $0.52-1.06$ \\
\hline High & $40(66.6)$ & 1.18 & $0.88-1.58$ \\
\hline \multicolumn{4}{|c|}{ Reduced professional fulfillment ${ }^{a}$} \\
\hline Low & $1(20)$ & 1.00 & \\
\hline Average & $47(50.5)$ & 2.52 & $0.43-14.7$ \\
\hline High & $54(59.3)$ & 2.96 & $0.50-17.2$ \\
\hline
\end{tabular}

Table 3 Association between burnout syndrome and abdominal adiposity by strata of sociodemographic and occupational characteristics, lifestyle, and morbidity, Bahia, Brazil, 2016

\begin{tabular}{llll}
\hline Variables & PR & Cl (95\%) & $p$ value $^{a}$ \\
\hline Crude PR & 1.69 & $1.33-2.14$ & \\
Sex & & & \\
$\quad$ Male & - & & - \\
$\quad$ Female & 1.65 & $1.30-2.09$ & \\
$\quad$ Adjusted PR & 1.65 & $1.30-2.09$ & \\
Age & & & 0.12 \\
$\quad$ Till 35 years old & 1.96 & $1.29-2.97$ & \\
$\quad$ 36 or more & 1.53 & $1.29-1.80$ & \\
$\quad$ Adjusted PR & 1.73 & $1.39-2.16$ & \\
Education & & & \\
$\quad$ High school & 1.62 & $1.37-1.91$ & \\
$\quad$ University & 1.72 & $1.01-2.93$ & \\
Adjusted PR & 1.65 & $1.33-2.05$ & \\
Physical activity practice & & & \\
Yes & 1.95 & $1.15-3.32$ & \\
No & 1.57 & $1.21-2.04$ & \\
Adjusted PR & 1.65 & $1.30-2.09$ &
\end{tabular}

Alcoholic beverage consumption

$\begin{array}{llll}\text { No } & 1.63 & 1.18-2.24 & \\ \text { Yes } & 1.75 & 1.21-2.53 & 0.76\end{array}$

$\begin{array}{lll}\text { Adjusted PR } & 1.67 & 1.31-2.13\end{array}$

Hypertensive

$\begin{array}{lll}\text { No } & 1.87 & 1.44-2.43\end{array}$

Yes

$\begin{array}{lll}\text { Adjusted PR } & 1.87 & 1.44-2.43\end{array}$

Diabetic

$\begin{array}{lll}\text { No } & 1.73 & 1.36-2.20\end{array}$

Yes

$\begin{array}{lll}\text { Adjusted PR } & 1.73 & 1.36-2.20\end{array}$

Anxious

$\begin{array}{lll}\text { No } & 1.48 & 0.96-2.27\end{array}$

$\begin{array}{lll}\text { Yes } & 1.82 & 1.37-2.40\end{array}$

0.43

$\begin{array}{lll}\text { Adjusted PR } & 1.71 & 1.33-2.21\end{array}$

Working time at a PHC unit

$\begin{array}{lll}\text { Up to } 4 \text { years } & 1.73 & 1.02-2.93 \\ 5 \text { or more years } & 1.52 & 1.29-1.79 \\ \text { Adjusted PR } & 1.59 & 1.28-1.97\end{array}$

0.54

${ }^{a}$ Breslow-Day homogeneity test

${ }^{\mathrm{a}}$ Fisher's exact test 
that the final obtained model has an adequate discriminative power, well-adjusted to the data (Table 4).

\section{Discussion}

Regarding the independent variable, our study found a prevalence of $10.6 \%$ for BS, especially with high $\mathrm{EE}$ (20.6\%), DP (31.7\%), and LPA (48.1\%). A study with PHC professionals found a prevalence of $39.3 \%$, indicating that about one third of primary care professionals have a high burnout level (Navarro-González et al. 2015). Another survey showed high EE (20.6\%), DP (21.1\%), and LPA (21.5\%) (Martins et al. 2014), with a high prevalence of AA in the surveyed professionals (54\%). Studies with nursing workers found inadequate $\mathrm{AA}$ in 61 and 50.72\% (Silveira et al. 2013; Sousa et al. 2007).

According to our knowledge, this is the first Brazilian research with $\mathrm{PHC}$ nursing professionals that studies the association of burnout with AA. No studies were found in the databases aiming to investigate this association. We highlight the positive association presented here, even after adjusting other variables of interest (adjusted PR 1.63; 95\% CI, 1.29 to 2.06).

The existence of a mechanism which mediates the relationship between AA and BS is stated. Based on the biological plausibility proposed in this study, the HPA axis would be related to burnout effects, since it is the result of prolonged exposure to chronic work stress (Miller et al. 2007; Oliveira et al. 2013). It is noteworthy that a study of chronic stress in British workers found an association between chronic occupational stress and the presence of metabolic syndrome (MS), with AA being a variable belonging to MS (Marmot and Brunner 2005).

Stimulation of the concerned axis would be associated with adipogenesis which results in general obesity and central obesity besides appetite stimulation (Brunner and Marmot 2006). Fat accumulation occurs predominantly in visceral adipose tissue of the abdomen, which has more cells per mass unit. In turn, AA is a risk factor for atherosclerosis and chronic cortisolemia, increasing the risk of cardiovascular diseases (Vale 2005).

In addition to the direct effects inherent to stimulation of the HPA axis, some authors mention the consumption

Table 4 Final model of the association between burnout syndrome and abdominal adiposity obtained by multivariate logistic regression

\begin{tabular}{lllll}
\hline Final model & $\begin{array}{l}\text { Crude } \\
\text { PR }\end{array}$ & $\mathrm{Cl}(95 \%)$ & $\begin{array}{l}\text { Adjusted } \\
\text { PR }\end{array}$ & $\mathrm{Cl}(95 \%)$ \\
\hline Burnout syndrome $^{\mathrm{a}}$ & 1.69 & $1.33-2.14$ & 1.63 & $1.29-2.06$ \\
Area Under the ROC Curve & & 0.71 & & \\
Goodness fit test $^{\mathrm{b}}$ & \multicolumn{3}{c}{$p$ value $=0.73$} \\
\hline
\end{tabular}

${ }^{a}$ Adjusted by age and working time at a PHC unit

bHosmer-Lemershow of alcohol and the increased intake of foods rich in fats and sugars as indirect effects inherent to stress confrontation and relief and consequently to burnout (KitaokaHigashiguchi et al. 2009).

A cross-sectional population-based study conducted in Brazil with a sample of 1054 company workers, aiming to investigate the factors associated with overweight and AA in both sexes, showed that the variables associated with AA in men were age (PR 1.02), high household income (PR 1.05), smoking (PR 1.36), hypertension (systolic blood pressure PR 1.41 and diastolic blood pressure PR 1.85), and hypertriglyceridemia (PR 2.29). In women, they were age (PR 1.02), alcohol consumption (PR 1.42), hypertriglyceridemia (PR 1.44), diastolic blood pressure (PR 1.65), and hyperglycemia (PR 1.71). The authors emphasize that the increase in body fat puts workers at possible risk of morbidity and early mortality (Araújo et al. 2010).

In this context, in our study, we found the following variables to be associated with $\mathrm{AA}$ : age (crude $\mathrm{PR}=1.61$; 95\% CI, 1.24 to 2.10 ); education (crude $\mathrm{PR}=1.6$; $95 \% \mathrm{CI}$, 1.20 to 2.11 ); hypertension (crude $\mathrm{PR}=2.02 ; 95 \% \mathrm{CI}$, 1.74 to 2.35 ); diabetes (crude $\mathrm{PR}=1.80 ; 95 \% \mathrm{CI}, 1.64$ to 2.16 ); working time in a $\mathrm{PHC}$ unit $\geq 5$ years (crude $\mathrm{PR}=$ 1.7; $95 \% \mathrm{CI}, 1.31$ to 2.24 ); and high $\mathrm{EE}$ (crude $\mathrm{PR}=1.39$; 95\% CI, 1.05-1.84).

In the scientific literature, we encountered a longitudinal study aimed to investigate the effects of burnout on risk factors for atherosclerotic disease in manufacturing company managers in Japan. The results showed new cases of increased WC, body mass index (BMI), and MS among the risk factors. Changes in WC, body weight, and BMI were significantly higher in professionals with burnout. The chances' ratio for the burnout group was 2.80 for hypercholesterolemia which was statistically significant after adjustment for age (KitaokaHigashiguchi et al. 2009).

Significant differences between the group of healthy professionals and the BS group in relation with WC were found. While the healthy group had a mean estimated variation of $0.6-\mathrm{cm} \mathrm{WC}$, the average variation in the burnout group was $2.4 \mathrm{~cm}$. While the healthy group usually lost weight, the group with BS gained it. Thus, burnout resulting from prolonged exposure to chronic work stress may be associated with risk factors for atherosclerotic disease and adipogenesis (Kitaoka-Higashiguchi et al. 2009).

Concerning the fact of not having identified statistically the presence of confounders in this study, some care was taken in the methods to reduce interference of possible variables that have an influence both on AA and BS. Thus, the covariates sex, age, education, physical activity practice, alcohol consumption, hypertension, diabetes, anxiety, and working time in a PHC unit were kept in the final analysis model. 
The age and working time variables remained adjusted in the final analysis model. In this context, BenevidesPereira (2010) emphasizes that burnout can express itself from the beginning of the employment with a possible externalization in a later stage, being an exhausting process that increases with time. Thus, Oliveira et al. (2009) demonstrated the inadequacy in WC and BMI according to increasing age in women and men, respectively.

\section{Conclusions}

The results of this study allow us to conclude that there is a positive association between BS and AA in the analyzed PHC nursing professionals. We found significant prevalence of burnout and AA. On the other hand, some limiting aspects may have weakened the interpretation of the findings of this study. Among them, there is the difficulty in understanding the chronological order of events or confirming causal relationships in cross-sectional studies, with the possibility of reverse causality, since the AA can act as exposure to the SB.

In this conjuncture, attempting to expand the knowledge of the discussed hypothesis, studies with more robust designs should be encouraged, including intervention and cohort studies, in an effort to observe if there is a reduction of the risk of AA with $\mathrm{BS}$ prevention and control so that preventive measures, such as the creation of public policies for occupational health, can become more pervasive.

\begin{abstract}
Abbreviations
AA: Abdominal adiposity; AC: Abdominal circumference; ACTH: Adrenocorticotropic hormone; BMI: Body mass index; BS: Burnout syndrome; Cl: Confidence intervals; DP: Depersonalization; EE: Emotional exhaustion; FHU: Family health units; HPA: Hypothalamic-pituitary-adrenal; LPA: Low professional accomplishment; MBI: Maslach burnout inventory; MS: Metabolic syndrome; OR: Odds ratio; PHC: Primary Health Care; PR: Prevalence ratios; ROC: Receiver operating characteristic; SPSS: Statistic Package for Social Sciences; WC: Waist circumference
\end{abstract}

\section{Acknowledgements}

The authors thank the Universidade do Estado da Bahia and the professionals who participated in the study.

\section{Funding}

This work was supported by the Fundação de Amparo à Pesquisa do Estado da Bahia (FAPESB) by encouraging with Scientific Initiation grants.

\section{Availability of data and materials}

Not applicable.

\section{Authors' contributions}

MCM and DSS conceived the idea for the study, contributed to the design of the research, were involved in the data collection, and discussed the data. IL analyzed the data. DSO, MCS, and ADJ edited the final version of the manuscript. All authors read and approved the final manuscript.

\section{Competing interests}

The authors declare that they have no competing interests.

\section{Ethics approval and consent to participate}

The study was approved by the Ethics in Research Committee involving human beings of the State University of Bahia, in decree no. 872.365/2014. We highlight that all participants signed the consent form.

\section{Author details}

'Universidade do Estado da Bahia, Departamento de Ciências da Vida. Rua Silveira Martins, 2555, Cabula, Salvador, Bahia CEP 41150000, Brazil. 2Programa de Pós Graduação em Ciências da Saúde, Universidade Federal da Bahia, Salvador, Bahia, Brazil. ${ }^{3}$ Programa de Pós Graduação em Saúde Coletiva. Universidade Estadual de Feira de Santana, Bahia, Brazil. ${ }^{4}$ UNEB,

Departamento de Educação, Campus XII, Guanambi, Bahia, Brazil.

Received: 15 July 2016 Accepted: 27 October 2016

Published online: 21 November 2016

\section{References}

Ammar, K. A., Redfield, M. M., Mahoney, D. W., Johnson, M., Jacobsen, S. J., \& Rodeheffer, R. J. (2008). Central obesity: association with left ventricular dysfunction and mortality in the community. American Heart Journal, 156, 975-981.

Araújo, M. S., Costa, T. H., Schmitz, B. A., Machado, L. M., \& Santos, W. R. (2010). Factors associated with overweight and central adiposity in urban workers covered by the Workers Food Program of the Brazilian Amazon Region. Revista Brasileira de Epidemiologia, 13(3), 425-433.

Benevides-Pereira, A. M. (2003). O estado de arte do burnout no Brasil. InterAçãoPsy, 1(1), 04-11.

Benevides-Pereira, A. M. (2009). MBI - Maslach Burnout Inventory e suas adaptações para o Brasil (Anais da 32a Reunião Anual de Psicologia, pp. 84-85).

Benevides-Pereira, A. M. (2010). Burnout: quando o trabalho ameaça o bem-estar do trabalhador (4th ed.). São Paulo: Casa do Psicólogo.

Björntorp, P. (2001). Do stress reactions cause abdominal obesity and comorbidities? Obesity Reviews, 2, 73-86.

Brunner, E., \& Marmot, M. (2006). Social organization, stress, and health. In M. Marmot \& R. G. Wilkinson (Eds.), Social determinants of health. New York: Oxford University Press.

Chandola, T. T., Brunner, E., \& Marmot, M. (2006). Chronic stress at work and the metabolic syndrome: prospective study. British Medical Journal, 332(7540), $521-525$.

Costa, M. B., Guércio, N. M., Costa, H. F., Oliveira, M. M., \& Alves, M. J. (2011). Possível relação entre estresse ocupacional e síndrome metabólica. $\mathrm{HU}$ Revista, 37(1), 87-93.

Coutinho, L. M., Scazufca, M., \& Menezes, P. R. (2008). Métodos para estimar razão de prevalência em estudos de corte transversal. Revista de Saúde Pública, 42(6), 992-998.

Davis, M. C., Twamley, E. W., Hamilton, N. A., \& Swan, P. D. (1999). Body fat distribution and hemodynamic stress responses in premenopausal obese women: a preliminar study. Health Psychology, 18, 625-633.

Francischi, R. P., Perreira, L. O., Freitas, C. S., Klopfer, M., Santos, R. C., \& Vieira, P. (2000). Obesidade: atualização sobre sua etiologia, morbidade e tratamento. Revista de Nutrição, 13(1), 17-28.

Francisco, P. M., Donalisio, M. R., Barros, M. B., Cesar, C. L., Carandina, L., \& Goldbaum, M. (2008). Medidas de associação em estudo transversal com delineamento complexo: razão de chances e razão de prevalência. Revista Brasileira de Epidemiologia, 11(3), 347-355.

Gil-Monte, P. (2003). El Síndrome de Quemarse por el Trabajo en Enfermería. InterAçãoPsy, 1(1), 19-33.

Goldbacher, E. M., Matthews, K. A., \& Salomon, K. (2005). Central adiposity is associated with cardiovascular reactivity to stress in adolescents. Health Psychology, 24, 375-384

Habicht, J. P., \& Butz, W. P. (1979). Measurement of health and nutrition effects of large-scale nutrition intervention projects. In R. E. Klein (Ed.), Evaluation of the impact of nutrition and health programs (pp. 133-189). New York: Plenum Press.

Hosmer, D. W., Lemeshow, S. (2000). Applied Logistic Regression, 2nd ed. New York: Jonh Wiley e Sons.

Kitaoka-Higashiguchi, K. K., Morikawa, Y., Miura, K., Sakurai, M., Ishizaki, M., \& Kido, T. (2009). Burnout and risk factors for arteriosclerotic disease: follow-up study. Journal Occup Health, 51(2), 123-131.

Limongi-França, A. C., \& Rodrigues, A. L. (2005). Stress e trabalho: uma abordagem psicossomática (4th ed.). São Paulo: Atlas. 
Marmot, M. G., \& Brunner, E. (2005). Cohort profile: the Whitehall II study. Int Epidemiol, 34, 251-256.

Martins, I. S., \& Marinho, S. P. (2003). P potencial diagnóstico dos indicadores da obesidade centralizada. Revista de Saúde Pública, 37(6), 760-767.

Martins, L. F., Laport, T. J., Menezes, V. P., Medeiros, P. B., \& Ronzani, T. M. (2014). Escotamento entre profissionais da Atenção Primária à Saúde. Ciência \& Saúde Coletiva, 19(12), 4939-4750.

Maslach, C., Jackson, S. E., \& Leiter, M. P. (1996). The Maslach burnout inventory — test manual (3rd ed.). Palo Alto: Consulting Psycologist Press.

Merces, M. C., Cordeiro, T. S., Santana, A. C., Lua, I., Silva, D. S., Alves, M. S. D'Oliveira Júnior, A. (2016). Burnout syndrome in nursing workers of the primary health care. Revista Baiana de Enfermagem, 30, 1-9.

Merces, M. C., Silva, D. S., Lopes, R. A., Lua, I., Silva, J. K., \& Oliveira, D. S. (2015). Síndrome de Burnout em Enfermeiras da Atenção Básica à Saúde: uma revisão integrativa. Rev Epidemiol Control Infect, 5(2), 100-104.

Miller, G. E., Chen, E., \& Zhou, E. S. (2007). If it goes up, must it come down? Chronic stress and the hypothalamic-pituitary-adrenocortical axis in humans. Psychological Bulletin, 133, 25-45.

Moreira, D. S., Magnago, R. F., Sakae, T. M., \& Magajewski, F. R. (2009). Prevalência da Síndrome de Burnout em trabalhadores de enfermagem de um hospital de grande porte da Região Sul do Brasil. Caderno de Saúde Pública, 25(7), 1559-1568.

Murofuse, N. T., Abranches, S. S., \& Napoleão, A. A. (2005). Reflexões sobre estresse e Burnout e a relação com a enfermagem. Rev Latino-am Enfermagem, 13(2), 255-261.

Navarro-González, D., Ayechu-Díaz, A., \& Huarte-Labiano, I. (2015). Prevalencia del síndrome del burnout y factores asociados a dicho síndrome en los profesionales sanitarios de atención primaria. Semergen, 41(4), 191-198.

Oliveira, C., Scarabelot, V. L., Cioato, S. G., Caumo, W., \& Torres, I. L. (2013). Interrelação entre síndrome metabólica, estresse crônico e ritmos circadianos de marcadores adipogênicos: uma revisão. Revista HCPA, 33(3/4), 257-268.

Oliveira, L. C., West, L. E., Araújo, E. A., Brito, J. S., \& Nascimento Sobrinho, C. L. (2015). Prevalência de adiposidade abdominal em adultos de São Francisco do Conde, Bahia, Brasil, 2010. Epidemio/ Serv Saúde, 24(1), 135-144.

Oliveira, L. P., Assis, A. M., Silva, M. C., Santana, M. L., Santos, N. S., \& Pinheiro, S. M. (2009). Fatores associados a excesso de peso e concentração de gordura abdominal em adultos na cidade de Salvador, Bahia, Brasil. Cadernos de Saúde Pública, 25(3), 570-582.

Ramirez, A. J., Graham, J., Richards, M. A., Cull, A., \& Gregory, W. M. (1996). Mental health of hospital consultants: the effects of stress and satisfaction at work. Lancet, 347, 724-728.

Ribeiro, R. P., Marziale, M. H., Martins, J. T., Ribeiro, P. H., Robazzi, M. L., \& Dalmas, J. C. (2015). Prevalência da Síndrome Metabólica entre trabalhadores de Enfermagem e associação com estresse ocupacional, ansiedade e depressão. Rev Latino-Am, 23(3), 435-440.

Rosmond, R., \& Bjorntorp, P. (2000). Occupational status, cortisol secretory pattern and visceral obesity in middle-aged men. Obesity Research, 8(6), 445-450.

Scarcela, C., \& Despres, J. P. (2003). Tratamiento de la obesidad: necesidad de centrar la atención en los pacientes de alto riesgo caracterizados por la obesidade abdominal. Cadernos de Saúde Pública, 19(Supl 1), 7-19.

Seigel, D. G., Podgor, M. J., \& Remaley, N. A. (1992). Acceptable values of kappa for comparison of two groups. American Journal of Epidemiology, 135(5), 571-578.

Silveira, C. D., Urbanetto, J. S., Silva, P. C., Magnago, T. S., \& Figueiredo, C. E. (2013). Perfil de sobrepeso e obesidade em trabalhadores de enfermagem em unidades de cuidado intensivo e emergência. Revista Ciência \& Saúde, 6(3), 157-162.

Smeltzer, S. C., Bare, B. G., Hinkle, J. L., \& Cheever, K. H. (2009). Brunner e Suddarth, tratado de enfermagem medico-cirúrgico (Vol. 2). Rio de Janeiro: Guanabara Koogan.

Sociedade Brasileira de Endocrinologia e Metabologia. (2005). 1 a Diretriz Brasileira de Diagnóstico e Tratamento da Síndrome Metabólica. Brazilian guideline for diagnosis and treatment of metabolic syndrome (in Portuguese). Ara Bras Cardiol, 84(Suppl. 1):3-28.

Sousa, I. F., \& Medonça, H. (2009). Burnout em professores universitários: impacto de percepções de justiça e comprometimento afetivo. Psicteor e Pesa, 25(4), 499-508.

Sousa, R. M., Sobral, D. P., Paz, S. M., \& Martins, M. C. (2007). Prevalência de sobrepeso e obesidade entre funcionários plantonistas de unidades de saúde de Teresina, Piauí. Revista de Nutrição, 20(5), 473-482.

Steptoe, A., \& Wardle, J. (2005). Cardiovascular stress responsivity, body mass and abdominal adiposity. International Journal of Obesity, 29, 1329-1337.
Tironi, M. O., Sobrinho, C. L., Barros, D. S., Reis, E. J., Marques Filho, E. S., \& Almeida, A. (2009). Trabalho e síndrome da estafa profissional (Síndrome de Burnout) em médicos intensivistas de Salvador. Revista Da Associacao Medica Brasileira, 55(6), 656-662.

Tsigos, C., \& Chrousos, G. P. (2006). Stress, obesity, and the metabolic syndrome: soul and metabolism. Annals of the New York Academy of Sciences, 1083, 11-13.

Universidade de São Paulo, Laboratório de Avaliação Nutricional de Populações. (2010). Manual de técnicas antropométricas: guia para realização de medidas antropométricas. São Paulo: Lanpop.

Vale, S. (2005). Psychosocial stress and cardiovascular diseases. Post grad Med Journal, 81, 429-435.

Waldstein, S. R., Burns, H. O., Toth, M. J., \& Poehlman, E. T. (1999). Cardiovascular reactivity and central adiposity in older African Americans. Health Psychology, $18,221-228$

World Health Organization. (2005). Preventing chronic diseases: a vital investment. Geneva: Health Agency of Canada.

\section{Submit your manuscript to a SpringerOpen ${ }^{\circ}$ journal and benefit from:}

- Convenient online submission

- Rigorous peer review

- Immediate publication on acceptance

- Open access: articles freely available online

- High visibility within the field

- Retaining the copyright to your article

Submit your next manuscript at $>$ springeropen.com 